No. 4096 May 1, 1948

already learned was much shorter in the facial region than in the recent large apes). There is a reasonable prospect that, in continuing their excavations during the coming season, Dr. Leakey and Dr. McInnes may be able to secure this important evidence. Meanwhile, it is not a little remarkable to find, as the result of the excavations in Kenya, that already in Early Miocene times East Africa was populated with numerous species of primitive apes ranging in close gradations of size from small creatures no larger than Hylobates to great apes of gorilloid dimensions.

${ }^{1}$ Broom, R., and Schepers, G. W. H., Transvaal Mus. Mem., No. 2 (1946).

${ }^{2}$ Dart, R., Nature, 115, 195 (1925).

${ }^{3}$ Broom, R., Nature, 159, 672 (1947).

4 Broom, R., and Robinson, J. T., Nature, 160, 153 (1947).

${ }^{5}$ Broom, R., and Robinson, J. T., Nature, 160, 430 (1947).

- Hopwood, A. T., J. Linn. Soc., 88, 437 (1933).

${ }^{7}$ Leakey, L. S. B., Nature, 152, 319 (1943).

${ }^{8}$ McInnes, D. G., J. East Africa and Uganda Nat. Hist. Soc., 17 (1943).

- Le Gros Clark, W. E., Nature, 160, 891 (1947).

\section{BRITAIN'S FUEL PROBLEMS}

$\mathrm{T}$

HE authoritative reports issued periodically by P.E.P. (Political and Economic Planning)an independent non-party organisation-have estab. lished for the compilers a reputation for clearly argued, factual and objective analyses to which industry and politicians alike may turn for guidance. Before the War, P.E.P. had issued reports dealing with the coal industry (1936), the electricity supply industry (1936) and the gas industry (1939) of Britain; all are now out of print. But for the War, a fourth report, on the co-ordination of the fuel and power industries, would have followed in natural sequence; and the need for such co-ordination became one of the principal reasons for the formation of the Ministry of Fuel and Power in 1942. "The British Fuel and Power Industries", published at the end of 1947*, reviews developments which have taken place since the earlier reports were issued. It does not argue the advantages or disadvantages of nationalization, and was prepared on the assumption that before long the major fuel industries would, in fact, be brought under national ownership. One aim was to indicate some of the steps necessary to bring these industries to a state of the fullest efficiency, and to suggest broad lines along which their co-ordination might be achieved.

The report invites use as a reference rather than as a book to be read; but an immediate clear summary of some fifty pages outlines the contents in bold precis. As most readers will make an approach from this summary, it might have been helpful had cross-reference been made in it to the 160 tables of valuable data which follow in the text. Both the summary and the text are arranged in four main sections; the first dealing with national resources, productive capacity and output; the second with consumption and market requirements (including a technical appendix relating to the iron and steel and textile industries), the third with organisation and relations with Government, and the fourth with co-ordination of the fuel and power industries.

It is estimated that on the basis of net useful therms supplied, coal accounted in 1945 for more

* The British Fuel and Power Industries. A Report by P.P.P. Pp. xi 406. (London: P.E.P., 1942.) 308. net. than 90 per cent of the total British fuel consumption, imported petroleum products (including motor spirit) for about 9 per cent, and hydro-electric power and oil from indigenous petroleum and shales for well under 1 per cent. Full development of hydro-electric resources, including those in Scotland and North Wales, might provide an equivalent of 3 per cent of present coal output; the potential output of the Severn Barrage is equivalent to 0.5 per cent. Except for the possibilities inherent in the development of atomic energy, no great change in the proportionate consumption stated is anticipated, unless by an increase in imports of petroleum products at the expense of the country's balance of payments; and while there are no grounds for anxiety regarding the adequacy of total supplies or of particular types of coal over the next hundred years, total proved reserves are much less than estimated forty years ago. No mention is made of possible coal reserves revealed by recent prospecting for oil.

The report indicates that the exhaustion of the best low-ash seams, the increased use of mechanical means of coal winning, etc., call for more extensive preparation of coal for the market, and full co-operation between the producer, consumer and appliance manufacturer; a major problem is the disposal of fine coal, and research and development work are necessary. In view of shortage of coal on the home market, exports have been restricted since 1941; it is debatable whether in the long run large quantities of coal, a wasting asset, should be exported, but coal exports at the level prevailing before the War would make a substantial contribution to the national economy.

With the rapid growth of electricity generation, use of waste heat from power stations represents an important potential contribution to fuel conserva. tion; and while there is scope for greater development of combined power and heating plants, the extensive development of district heating to utilize waste heat from existing power stations is considered economically impracticable. The possibility of district heating should, however, be taken into account in deciding the location of new power stations.

In the iron and steel industry, better geographical distribution and further integration are most likely to reduce fuel consumption. Blast furnaces are the most important single fuel-consuming plants, the coal equivalent of the coke consumed therein increasing from 6 per cent of total coal output in 1937 to nearly 8 per cent in 1944 ; increase in size of blast furnaces is desirable. In the textile industries, spaceheating accounts for 70 per cent of the total fuel consumption in cotton weaving and for 40 per cent in worsted spinning; indeed, the seasonal nature of industrial fuel consumption suggests that the use for space-heating is considerable.

It is stated that a sound national fuel policy can be based only on a detailed knowledge of trends in fuel usage, and fuller information is necessary. Much has been obtained by various fuel efficiency com. mittees and Government departments, but little has yet been collated and published; indeed, there is need for a regular audit of the fuel balance of all industrial users. On grounds of thermal efficiency, the large amount of coal used for steam raising is unlikely to be replaced by any form of processed coal or alternative fuels; in furnace firing, the overall efficiency of utilization of coal is low, and gas, liquid fuel or electricity have technical advantages in partic- 
ular instances. Solid fuel will be compelled to carry the main load for domestic use for many years to come, if only because in this form sufficient stocks can be provided to meet peak loads ; for continuous space-heating of domestic premises, the most efficient appliances are solid-fuel closed or closable fires, and gas fires with convection.

After reviewing technical considerations affecting uses, the report passes to discussion of the possibilities of tariff co-ordination as a means for securing the best use of the national fuel resources of Britain, but without being able to lay down any novel basis. In order that consumers' choice of fuel coincides with national interest regarding resources and smoke abatement, close attention should be paid to the tariff structure of individual fuel supply industries; subject to certain exceptions to cover promotional tariffs and the uneconomical consumer, tariffs should be closely related to cost of production and supply. Special importance is attached to regulation of coal prices ; relative prices for various grades and qualities must exert strong influence on trend of consumption and rate of development of the gas and electricity industries. The report recognizes the difficulties involved, and proposes tariff commissions for individual industries, guided by a national authority, probably the Ministry of Fuel and Power ; while unrestricted price competition is undesirable, administrative and technological competition has on the whole been of great benefit. There is a serious shortage of fuel technologists and the knowledge of the general public is small.

Even if the report leaves one a little in the air, it is invaluable at the present moment; it will serve for some time as the most readily available guide. Reference may perhaps be made to the remarkable statement on page 131 : "the earth's internal store of thermal energy is dependent for its maintenance on solar radiation"; and an omission in discussing possible future trends is reference to the gas turbine, for opinion recently expressed is that the raw coal turbine looks to most engineers a likely practical proposition for industrial service years ahead of atomic energy.

D. T. A. ToWNEND

\section{UNIVERSITY OF PRAGUE SEXCENTENARY CELEBRATIONS}

\section{By DR. GERALD DRUCE}

$\mathrm{T}$ HE six hundredth anniversary of the founding of the Charles University of Prague was cele. brated during the week commencing April 4. The precise date of its foundation is usually given as April 7, 1348, the day on which Charles, as King of Bohemia, issued his charter setting out the reasons for the institution of a seat of higher learning in the Czech capital. Until 1355, when the Carolinum was ready, tuition had to be given in religious buildings and in private houses that had previously served as Latin schools. The original building, enlarged and renovated, still serves for important University functions and was used for some of this year's ceremonies. For the general gatherings use was made of the large Vladislav Hall of the Hradcany Castle, which is capable of seating several thousands.

The first assembly was mainly for Czechoslovak participants, and included, as well as members of the
University, several Cabinet Ministers, prominent ecclesiastics, authors and representatives of the arts and sciences, workers' educational associations and students. The Czechoslovak Premier, Mr. Klement Gottwald, reminded the assembly that during its long history the University had given the world many great men of science and thinkers and that it entered upon its seventh century at a time of considerable social and economic change from which, it is hoped, a better world is being born. In such a world the University will have a still greater mission to fulfil since more scientific men and other scholars than ever before will be needed.

Prof. Bohumil Bydžovský, rector of the University, dealt at length with the University's significance for the nation's cultural and intellectual life. "For us the Carolinum is a symbol of the struggle for truth and for spiritual and ethical perfection and progress.' H.e stressed the contributions of John Hus and of T. G. Masaryk at different stages of its history. Prof. Z. Nejedily, Minister for Education and president of the Czech Academy, pointed out that the University has always been associated with national aspirations and its influence to-day is as great as ever, and so are the tasks before it.

Messages of congratulation were given by Profs. Seifert and Ryšaví respectively, on behalf of the sister University of Brno and the Prague Technical College, and by a representative of the students.

On the actual anniversary, the hall was filled with distinguished people and students when the procession of foreign delegates, the rector, members of the Senate, the deans and professors of the Charles University and of the other Czechoslovak universities entered. The rector escorted President Bent to his seat, welcoming the visitors in short speeches in four languages, referring again to the University's part in the nation's historical evolution. He mentioned its early contacts with other universities, especially those of Paris and Oxford, expressing gratitude to Oxford in particular for allowing Czech students to complete their studies there when the Czech universities were closed in 1939. He expressed his deep regret that British universities and those of some other countries had not accepted the invitations to participate in this historic ceremony.

In presenting the renewed charter, written on parchment by Prof. J. Benda of the School of Fine Arts, to replace the original that disappeared during the German occupation, President Ben€ š pointed out how moral and political issues profoundly affected the fate of seats of learning, which could always be found on the side of recognized truth, liberty and morality. It was from the University that so many honorable and wise men arose to lead the nation in both glorious and difficult times; but the Charles University had never been able to celebrate its centenaries in peace and tranquillity. Its first centenary occurred when King George of Pod rbrady was vainly trying to set up the first league of nations. In 1548 the first Czech revolt against the Habsburgs was being heavily suppressed. The Peace of West. phalia in 1648 followed the Thirty Years War that had devastated and depopulated the kingdom, then in bondage with the University in foreign hands. The year 1748 fell between two more wars that were disastrous for the Czech people, apart from the added contemporary dangers of Austrian measures of centralization and Germanization. Finally, the year 1848, which brought the beginnings of constitutionalism to the Slavs, was also one of storms, and not 